Goldschmidt 2021 Abstract

https://doi.org/10.7185/gold2021.3623

\section{Geochemical controls on arsenic mobilization in a potential permeable natural reactive barrier (PNRB)}

\author{
TOM S VARNER ${ }^{1}$, HARSHAD VIJAY KULKARNI ${ }^{1}$, \\ WILLIAM NGUYEN ${ }^{2}$, M. BAYANI CARDENAS ${ }^{3}$, \\ KYUNGWON KWAK ${ }^{4}$, PETER KNAPPETT ${ }^{4}$, MESBAH \\ UDDIN BHUIYAN $^{5}$, KAZI M AHMED 5 , SYED AHKTER ${ }^{5}$ \\ AND SAUGATA DATTA ${ }^{1}$ \\ ${ }^{1}$ University of Texas at San Antonio \\ ${ }^{2}$ University of Texas \\ ${ }^{3}$ The University of Texas at Austin \\ ${ }^{4}$ Texas A\&M University \\ ${ }^{5}$ University of Dhaka \\ Presenting Author: tom.varner@my.utsa.edu
}

Elevated concentrations of arsenic (As) in groundwater pose serious health concerns. Riverbank sediments along the Meghna river, Bangladesh enriched with iron (Fe)-oxy(hydroxides) have been shown to release adsorbed As under reducing conditions. Recent studies hypothesize that the mixing of oxic river water with $\mathrm{Fe}$ and As-rich reduced groundwater within shallow riverbank sediments cause Fe-oxide minerals to precipitate and accumulate As on their surfaces, acting as a permeable natural reactive barrier (PNRB).

Here we discuss data from riverbank sediment cores collected along a transect orthogonal to a generally gaining reach of the Meghna River (0-83m from the river, 0-3m depth) to test for a possible PNRB. Sediment samples were analyzed to identify zones of enriched $\mathrm{As}, \mathrm{Fe}, \mathrm{Mn}$ and association of other key elements using X-Ray Fluorescence (XRF). Fe(II) concentrations were determined by spectrophotometric analysis following $\mathrm{HCl}$ extraction. Sediment samples were incubated with deionized water under oxic conditions to simulate the geochemical interaction between the river water and sediments. The resulting extracts were analyzed for the major ion and trace element concentrations.

Results show that the riverbank sediment samples are primarily composed of fine sands with unevenly distributed $\mathrm{As}_{\mathrm{T}}$ (5-10mg/kg). solid-phase $\mathrm{Fe}_{\mathrm{T}}$ varied between $29-53 \mathrm{~g} / \mathrm{kg}$ and $\mathrm{Fe}(\mathrm{II})$ concentrations varied between $2-25 \mathrm{mg} / \mathrm{kg}$. Solid-phase $\mathrm{Fe}_{\mathrm{T}}$ and $\mathrm{Mn}_{\mathrm{T}}(475-860 \mathrm{mg} / \mathrm{kg})$ were positively correlated, decreasing from the river edge to $20 \mathrm{~m}$ inland. The decreasing $\mathrm{Fe}_{\mathrm{T}}$ and $\mathrm{Mn}_{\mathrm{T}}$ along this distance demonstrate the weakening influence of infiltrating river water, highlighting the presumed extent of a potential PNRB. The abundance of water-extractable cations was $\mathrm{Na}^{+}>\mathrm{Ca}^{2+}>\mathrm{K}^{+}>\mathrm{Mg}^{2+}$, while that of the anions was $\mathrm{Cl}^{-}>\mathrm{PO}_{4}{ }^{2-}>\mathrm{SO}_{4}{ }^{2-}$. The low concentration of total dissolved solids (TDS) in the riverbank extracts $(5.4 \mathrm{mg} / \mathrm{L})$ relative to that of aquifer extracts at $2-37 \mathrm{~m}$ depth $(90.2 \mathrm{mg} / \mathrm{L})$ indicates the flushing of riverbank sediments with oxic river water. This flushing, while removing exchangeable ions from mineral surfaces, may promote the oxidation of Fe-oxides and removal of dissolved As from discharging groundwater. The results of this study, along with pore-water chemistry, and observed hydraulic properties will be integrated into a reactive transport model to better understand the fate of As within riverbanks. 